\title{
THE TONGUE AND THE REED: ORGANS AND INSTRUMENTS IN THE PHILOSOPHICAL PART OF HIPPOCRATIC REGIMEN
}

\author{
PAUL DEMONT \\ Université de Paris-Sorbonne*
}

\begin{abstract}
In the first book of Hippocratic Regimen, an unclear excursus explains how the technai imitate, and thus allow us to understand, human nature. It is argued here that the new polysemy of the word organon at the beginning of the fourth century is utilized by the author in his comparison, that this observation allows new understandings of some difficult passages and that such polysemy applies to a specific organon, the glotta ('tongue' and 'reed').
\end{abstract}

Keywords: Medicine, music, cookery, Hippocrates, techne

Medicine is one of the technai that promotes the idea of human superiority over animals. It applies to the human body, and doctors have compared the working of the human body to other technical operations. Nowhere is this comparison so systematic as in a difficult excursus on technai in the philosophical part of Regimen I, a Hippocratic treatise probably written before Plato's Timaeus. ${ }^{1}$ There, nature and art are carefully intertwined. ${ }^{2}$ The aim of this excursus is explained at the very beginning, where the author focuses on human nature:

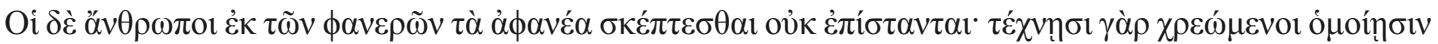

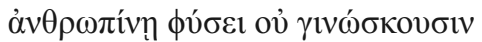

Men do not understand how to observe the invisible through the visible. For though the arts they employ are like the nature of man, ${ }^{3}$ yet they know it not (Reg. I.11, 134.21-22 J-B).

This human misunderstanding will be corrected by the author. Various affections $(\pi \alpha \theta \eta \dot{\eta} \mu \alpha \tau \alpha, 12$, 136.5 J-B), visible or invisible, act upon men: in his characteristic Heraclitean style ${ }^{4}$ he claims he can show that these affections are similar to technical procedures. In the debate between those who think that it is not possible to observe what is not visible ( $\varphi$ vepóv) and those who assert that it is possible to understand it, even when we can not see it, the thoughtful physician has found his

* paul.demont@paris-sorbonne.fr. I am grateful to many audiences (Berlin-FIEC, Palermo, Rethymnon, Stanford and Reims), to the anonymous readers of JHS, to Roger Brock and especially to Annie Bélis, whose suggestion about the meanings of glotta, after reading Demont (2004), has proved to be very important. The English version of this paper has benefitted from the help of Katie Hartsock (Northwestern).

${ }^{1}$ Reg. I.11-24 Joly and Byl. Unless otherwise mentioned, I quote Jones' translation of Regimen (1931) and translate quotations from secondary literature. The influence of Regimen on Timaeus has been suggested independently by Olerud (1951) 64-66; Jouanna (2012) 195-228; see also Joly and Byl (2003) 46; already Joly (1960) 52, 70-71.

2 See Bollack (1965) 300 n.4, also 299 (with n.4).

3 The transition from nature as a whole to human nature is not entirely clear. Fredrich (1899) thinks that the version of Regimen we have was written by a 'compiler' who used another treatise, written by a 'physicist' (111-22, bibliographical survey of the 19th century on p. 90). Here he supposes that the adjective $\alpha v \theta \rho \omega \pi i v \eta n$ has been added to a sentence about nature (of the whole world) and techne (144). But Joly correctly explains the limitation of the scope to human nature by 'a kind of a fortiori argument' asking 'how could men see that their body imitates the world? They don't even see that their technai imitate their own nature' (Joly and Byl (2003) 243-44). In the following chapters, Fredrich would like to separate the terms of the comparisons, each of them being in his opinion written by a different author.

${ }^{4}$ Diels published this section in his Vorsokratiker as Heraclitean imitation (DK 22C1). Joly (1960) 26 shows that the main influences are Anaxagoras, Archelaos and Pythagoreans 19-22. 
own way: if valid comparison can be made between pathemata and technai, we should consider that while some pathemata are visible and others are not, the technai are always visible. Thus we can assert the possibility of understanding even invisible pathemata. ${ }^{5}$

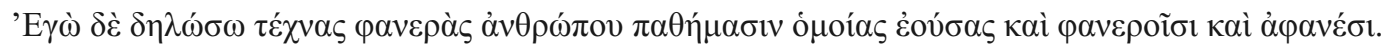

But I will show that arts are visibly like to the affections of men, both visible and invisible (I.12, 136.5$6 \mathrm{~J}-\mathrm{B})$.

In this paper it will be argued that the author uses the polysemy of ö $\rho$ yovov in his demonstration, particularly regarding one specific kind of ö $\rho \gamma \alpha v o v$, i.e. the $\gamma \lambda \tilde{\omega} \tau \tau \alpha$. This argument could contribute to the resolution of difficult problems in the text.

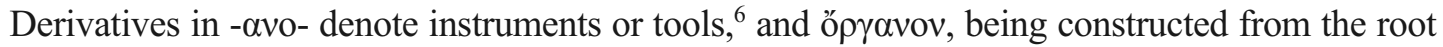
of हैpyov, means 'instrument', 'tool' with a general reference. Hence the word could be used for different kinds of tools or instruments (often musical instruments) and metaphorically with reference to '(bodily) organs'. When does this metaphorical connotation constitute a separate meaning? The answer is not easy. Plato often makes use of opyovov to refer to the sense-organs, especially in Theaetetus (184d4, 185a5, 185c7, 185d9), and the word still has the meaning of 'instrument' in the

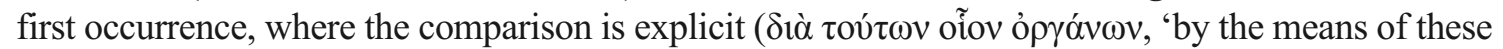

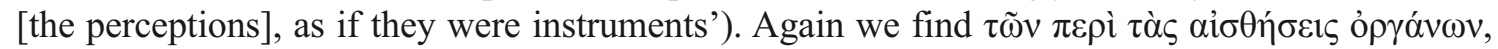
'instruments [or organs?] related to perceptions', in the sixth book of the Republic, opposed to ópyavóv

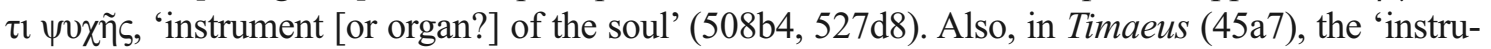
ments' (or 'organs'?) for seeing, hearing, etc. are created 'in order to let the soul prevent anything'.

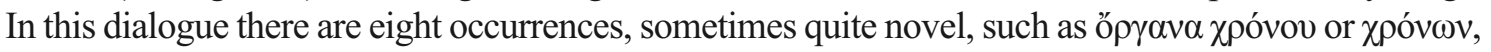
'instruments of time', i.e. the planets). The word is also used for a 'tool' (or an 'organ'? - evidently the belly is referred to) for receiving food and expelling it once its ikmas has been extracted (33c4). ${ }^{7}$

The Hippocratics use the word for the instruments and tools of the physician, but there are also several occurrences in which the meaning '(bodily) organ' seems to appear, in Epidemics VI and in Regimen. In the composite, and unclear, treatise Epidemics VI, Manetti and Roselli translate $\dot{\eta}$

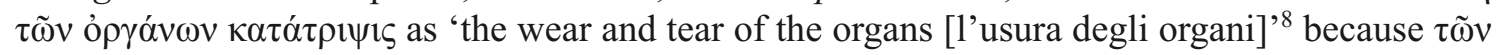
ópyó $v \omega v$ is at the end of a list of bodily features (skin, belly, flesh, vessels, brain, hair and organa).

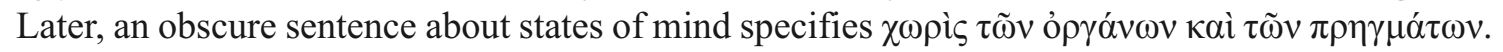
Through a comparison with a section in Humours, Manetti and Roselli understand 'regardless of the sense organs [organi di senso] and other actions.' 9 There it seems that the word alone could denote bodily organs without any further specification.

Moreover a passage in the excursus of Regimen is most interesting:

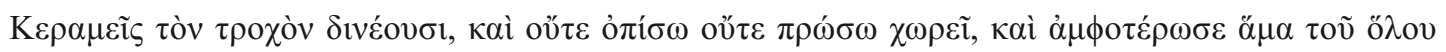

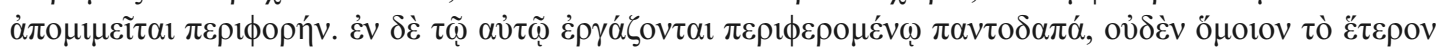

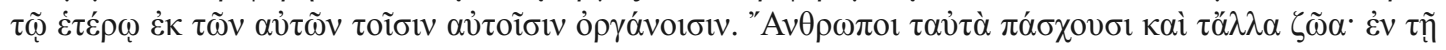

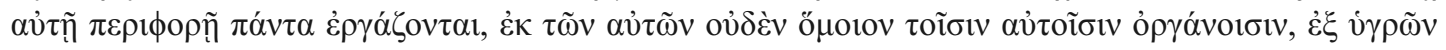

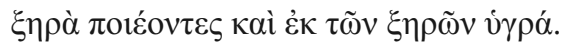

\footnotetext{
5 Joly (Joly and Byl (2003) 244) quotes Anaxagoras DK 59B21a; Jouanna (2002) 229, on Nature of Man 1.1, adds Heraclitus DK 22B54 and Breaths 3.3; see also Art 11.

${ }^{6}$ Chantraine (1979) 198.

7 Byl (1971) thinks there are in Plato six occurrences of ópravov as 'sense-organs' and one as 'bodily organ', without distinguishing meaning and reference. These texts may be posterior to Regimen.
}

8 Epid. VI 3.1, 52-53 M-R.

${ }^{9}$ Epid. VI 8.10, 174-75 M-R (cf. Hum. 9, V.490 Littré). This passage is close to Regimen IV.86.2 (where ópyova do not appear), a parallel noticed by several scholars, especially Joly, whose conclusion is that Epid. VI 'indeed is a pastiche, with alteration, of' Regimen (Joly and Byl (2003) 40). 
Potters spin their wheel, which shifts neither forward nor backwards, yet moves both ways at once, therein copying the revolution of the universe. On this wheel as it revolves they make pottery of every shape, and no two pieces are alike, though they are made from the same materials and with the same organa. Men and animals too are in the same case. In one and the same revolution they make all things, without two being alike, from the same materials and with the same organa, making dry from moist and moist from dry (I.22, 140.11-16 J-B).

This section first describes the work of potters as an imitation of the universal rotation of the world. This is related to the description of fire in the kosmos just before the excursus (chapter 10)

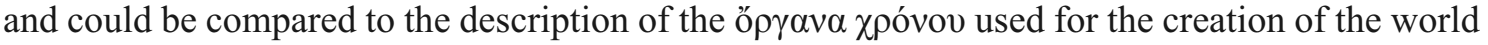
in Timaeus. Human nature is compared and narrowly linked to the nature of the whole universe. ${ }^{10}$ But this is not the main point. Here, although rolling, the potters' instruments remain the same during their work and nevertheless create different vessels. In the same way, men and animals always have the same organa, although through them they produce opposite things, 'making dry from moist and moist from dry'. Joly notes that this observation is very similar to the last observation of the previous chapter, which compares human bodies 'moistening the dry and drying the moist' to sculptors as they imitate the human body, 'drying the moist and moistening the dry' (chapter 21). Furthermore this expression was already used in chapter 17 about the architects imitating human diet:

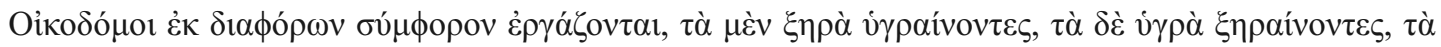

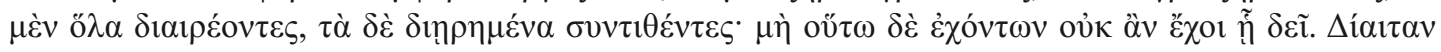

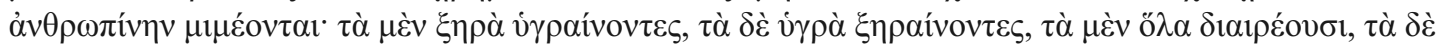

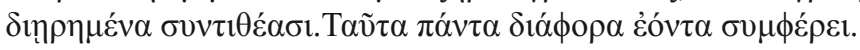

Builders out of diverse materials fashion a harmony, moistening what is dry, drying what is moist, dividing wholes and putting together what is divided. Were this not so, the result would not be what it should. It is a copy of the diet of man; moistening the dry, drying the moist, they divide wholes and put together what is divided. All these being diverse are harmonious (I.17, 138.9-13 J-B).

As Joly also notes, $\tau \alpha \hat{\tau} \tau \grave{\alpha} \pi \alpha ́ \sigma \chi 0 v \sigma \mathrm{r}$ ('are in the same case') is the standard formula after the description of a techne before explaining human physiology. Therefore I would agree with him that the word of $p \gamma \alpha v \alpha$ is used with the meaning '(bodily) organs', and not 'instruments' as Byl would prefer to interpret it. ${ }^{11}$ More precisely, these organs may refer to the belly, where the digestion takes place, as they do in Timaeus 33c4 quoted above. The two uses ${ }^{12}$ of ó $\rho \gamma \alpha v \alpha$ in this chapter do suggest a quite conscious interplay between the references to 'instrument' and to '(bodily) organ'. The very existence of o $\rho \gamma \alpha v \alpha$ both in the technai and in the body justifies the method adopted by the author of Regimen.

There are two further uses of ópyavov in Regimen I, but they are bracketed by Joly and others as glosses. ${ }^{13}$ I would like to discuss these occurrences again in their context.

In the excursus the comparisons between technai and pathemata are introduced by different

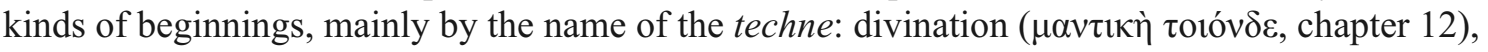

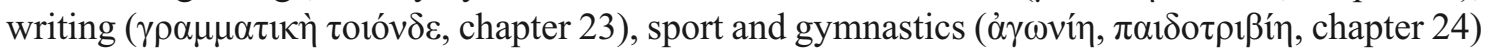

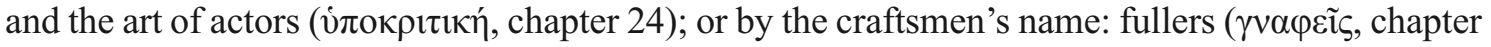

10 This is related to the 'a fortiori argument' (n.3).

11 Joly and Byl (2003) 248: Byl (1971) 124-26 'would think that here also it means tool, but admits that it could mean organ'. Jones (1931) translates in both cases by 'tools.'

\footnotetext{
12 The word is present twice in $\theta$ and in the ancient Latin translation, once in $\mathrm{M}$.

${ }^{13}$ Byl (1971) does not consider them. Jones (1931) keeps one of these references in his text.
} 


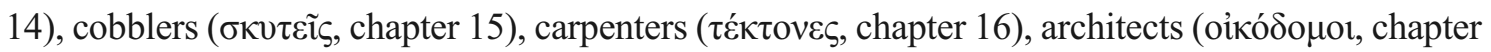

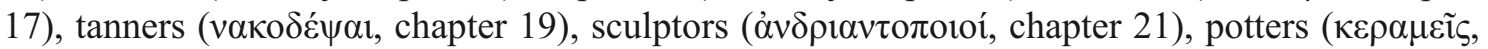
chapter 22). Craftsmen are also twice introduced only by verbs, without any subject, that describe them working gold and preparing corn ${ }^{14}$ (chapter 20). Lastly, in the transmitted text, there are two occurrences where the author mentions the organa of a techne.

Divination is the first techne described (elliptically and without any link to the preceding sentence). This skill provides evidence for knowing the future through invisible signs. That it is indeed a techne is well known. ${ }^{15}$ That medicine is related to divination is also well known; the two crafts know past, present and future, with the help of signs not understandable by laymen ${ }^{16}$ and rather 'fantastic'. ${ }^{17}$

After divination, the author takes the example of metallurgy, in a passage that is edited by Joly as follows (chapter 13):

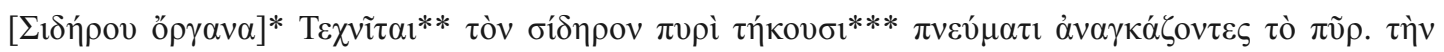

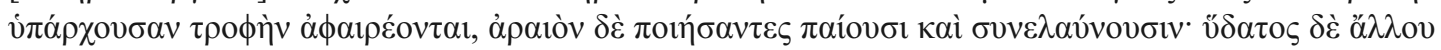

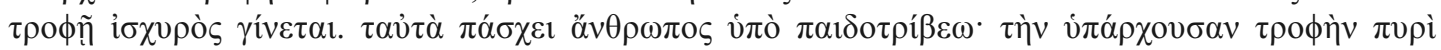

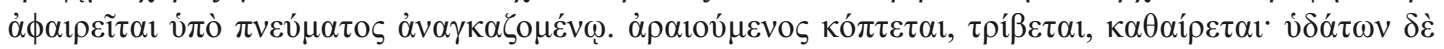

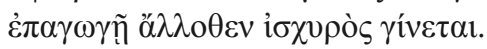

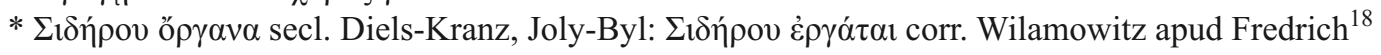

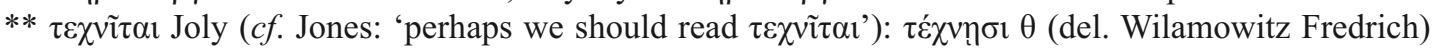
$\tau \dot{\varepsilon} \chi \vee \eta \varsigma \mathrm{M}$

*** farie (ferrarie Diels) artis hominis ferrum consumunt Lat.

Here is another application of the author's doctrine about fire and water as fundamental elements in the world. The first two words have been bracketed or corrected by editors because they seem to be inserted glosses, but not by Jones, although he suggests a correction. The introduction of

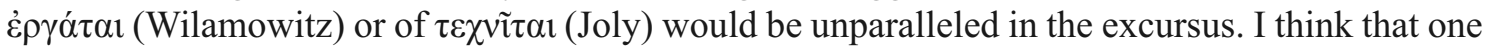
should come back to the conservative attitude of Littré and Jones, and read:

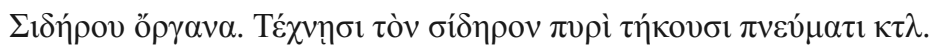

Iron tools. By their arts, craftsmen melt the iron with fire, constraining the fire with breath; they take away the nourishment it has already; when they have made it rare, they beat it and weld it; and with the nourishment of other water it grows strong. Such is the treatment of a man by his trainer. By fire the nourishment he has already is taken away, breath constraining him. As he is made rare, he is struck, rubbed and purged. On the application of water from elsewhere he becomes strong (I.13, 136.15-20 J-B).

The comparison is not between the craftsmen and men, but between iron and the human body; by observing the blacksmith's technique, and its ability to harden and mould iron, one can understand

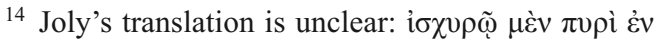
$\tau \tilde{\omega} \sigma \omega ́ \mu \alpha \tau \imath$ ở $\sigma v v i ́ \sigma \tau \alpha \tau \alpha 1, \mu \alpha \lambda \alpha \kappa \tilde{\omega} \delta \dot{\varepsilon}$, 'avec un feu violent, il ne prend pas dans le corps, mais bien au feu doux'. The comparison seems to be between the preparation of gold and of corn on the one hand, and digestion

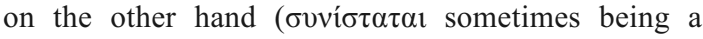
synonym for $\tau \rho \varepsilon \dot{\varepsilon} \varphi \tau \tau \alpha 1, c f$. Demont 1978): 'in the body, it is not with a violent fire, but with a smooth one, that man takes his form'.

15 See Aesch. Prom. 476-500; with Lloyd (1979) 227.

16 Jouanna (1999) 100-03.

17 Lloyd (1966) 354. Divination 'imitates the physis and the life of men', in which men, when having sex with women (a visible act), know that they will have children who will become adults (a yet invisible result). The second example (not commented on by Joly) is unclear, unless it alludes to (animal?) dissection: living beings are not the same alive and dead, but 'one knows the living being ( $\tau$ ò $\zeta \tilde{\omega} o v)$ by means of the dead' (my translation); about animal dissection with conclusions for human physiology, see Sacred Disease 11.3-4 (p. 22 Jouanna); Internal Affections 23 (Littré 7.225); with, for example, Lloyd (1979) 156-65; Boudon-Millot (forthcoming). Last example: the belly is not intelligent but it is nevertheless a means of knowing that we are hungry or thirsty.

${ }^{18}$ Fredrich (1899) 117: 'who thinks that $\tau \varepsilon ́ \chi v \eta \emptyset \sigma l$ comes from the varia lectio $\tau \varepsilon \chi v i \tau \alpha \imath$ '. 
the way fire, water and breath also change and mould the human body. Remarkably, there is another techne with such observable results, that of the paedotribes: men can observe similar effects of their training upon athletes.

This choice is in my opinion strengthened if we notice that in the transmitted text there is another example beginning with öpyavov, and comparing still more exactly a technical and a physiological őp $\gamma \alpha v o v$.

Here a brief philological note on the text of Regimen I is necessary. It is based on two ancient manuscripts: M (Marcianus graecus 269, tenth century) and $\theta$ (Vindobonensis medicus graecus 4,11 th century). But, thanks to Joly and Deroux, ${ }^{19}$ it is also possible to use an ancient Latin translation (Parisinus latinus 7027, ninth century), a text that could go back to the sixth century. Therefore, this Latin translation is our earliest testimony. It is very obscure and sometimes even impossible to understand; often the translator simply copies the Latin word for the Greek word, without understanding what he reads. ${ }^{20}$ Joly, who devotes a paper to it,${ }^{21}$ thinks that the two ancient Greek manuscripts and this translation all go back to the same tradition and therefore have common mistakes, which should be corrected. Nevertheless in the $C M G$ edition he recognizes that 'at least [the Latin translation] did confirm important conjectures and allow Diels to suggest several others'. ${ }^{22}$ I would add that one should be cautious in suspecting common mistakes between Lat., $\theta$ and $\mathrm{M}$; the Latin translation, of course, does reinforce the Greek tradition.

In my opinion, ${ }^{23}$ this is the case in chapter 18 , which concerns music and ... cookery. Here I would suggest retaining the transmitted text, as Littré does, although Fredrich, Jones and Joly bracket a whole sentence at the beginning of the chapter, 'as a marginal note which has been incorporated into the text' (Jones). Here is the beginning of the chapter, as it is edited and translated by Joly, with partial apparatus, and the text of the Latin translation with Deroux's apparatus:

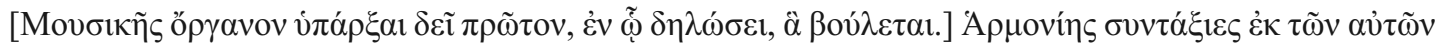

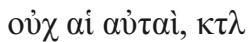

Des compositions musicales sont diverses, tout en provenant des mêmes (notes) ...

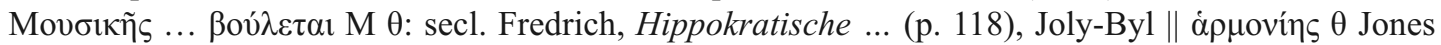

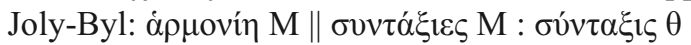

[De musicis] Musicum organum sic debet esse: primo erit in ea compaginationem ut quod uult illud significet concentu harmonie et coniecture ex semet ipsis dissimiles, non eaedem, ...

erit: ergo $P \|$ concentu harmonie: concerto sermone $P \|$ coniecture: coniecturam $P$

Again, such a beginning as the bracketing leaves us would be unparalleled in the excursus. Moreover, the reference to an of $\rho \gamma \alpha v o v$ is in accordance with the beginning of chapter 13 . The

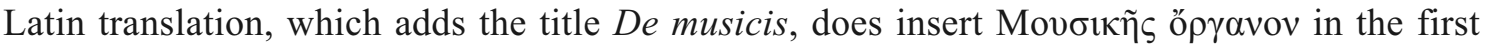
sentence. The author is now going to compare a musical instrument (and not music in general) with some physiological process. As in other chapters, the logic of the argument is difficult to grasp. Let us first read the explanation about this instrument. The Latin translation (compaginationem) seems to show that the Greek word $\alpha \rho \mu$ ovín or $\dot{\alpha} \rho$ ovíns belongs to the first part of the sentence, so that I will try to translate the text of M:

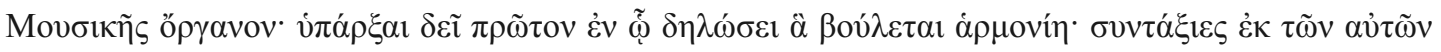

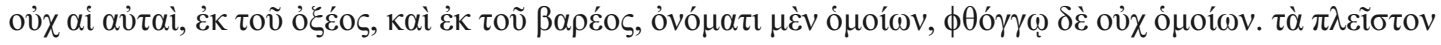

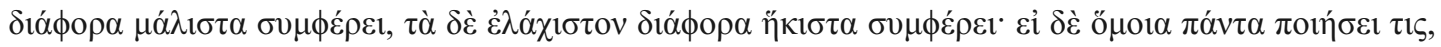

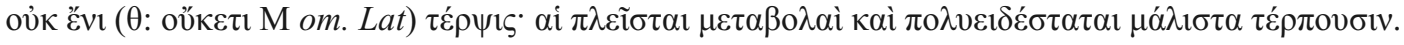
$81-83$.

19 Deroux and Joly (1978); see Joly and Byl (2003)

\footnotetext{
${ }^{20}$ See Deroux in Deroux and Joly (1978) 131.
}

${ }^{21}$ Joly (1975).

22 Joly and Byl (2003) 83.

23 See already Demont (2004). 
A musical instrument: firstly, that by which the meaning of harmony is made clear. Chords coming from the same elements are different, from the high and from the low, alike in name but not alike in sound. Those that are most diverse make the best harmony, those that are the least diverse make the worst. If somebody makes everything similar, it would fail to please; it is the greatest changes and the most varied that please the most (I.18, 138.14-18 J-B). ${ }^{24}$

The author has an excellent command of music, as is shown in the difficult chapter 8 of book I about correct harmonies. This chapter recalls a quotation of Philolaos (and proves that this quotation preserves authentic material), whose musical terminology, Barker writes, is here 'transposed into the Attic dialect' (DK 44B6a); in Regimen, such harmony is 'the principle which must govern relations between diverse elements in the developing fœtus if it is to become a living whole, and a structure spanning the compass of an octave, properly organised into substructures spanning a fourth and a fifth'. ${ }^{25}$ Without such harmony there would be no more tonos and no possibility for the instruments to be in agreement with voices. Barker's observations on tonoi are worth quoting: 'In the fifth and early fourth century, conceptions of tonoi and of the ways in which they were related arose directly from the observation of current musical practice, rather than constituting a body of theory from which practices were derived. Extensive modulation was particularly characteristic of music performed on wind instruments (auloi) ${ }^{\prime} \cdot{ }^{26}$ And he notes that the reed-blown pipes called auloi were the main reference for the harmonikoi. ${ }^{27}$ This importance of practical knowledge for techne is attested by Plato in his Republic, when he speaks about the discussions between harmonists upon string instruments. ${ }^{28}$ Here Regimen refers to a kind of instrumental music that is looking for the utmost pleasure, by means of complex, surprising and various harmonies. This is exactly, in my opinion, the same new music that was mocked in comedy and strongly criticized by Plato: in his Callipolis, there would not be any such depraved music.

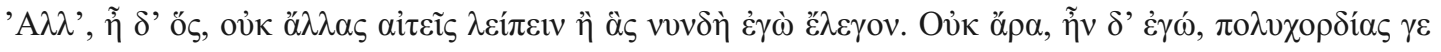

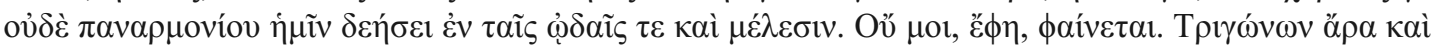

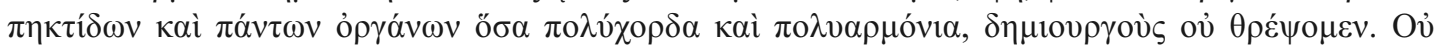

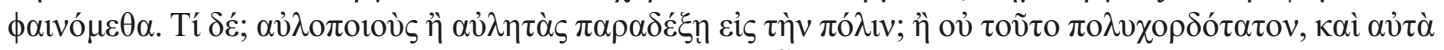

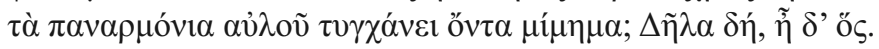

- Then, I said, if these and these only are to be used in our songs and melodies, we shall not want multiplicity of notes or a panharmonic scale? - I suppose not. - Then we shall not maintain the artificers of lyres with three corners and complex scales, or the makers of any other many-stringed curiouslyharmonised instruments? - Certainly not. - But what do you say to flute-makers and flute-players? Would you admit them into our State when you reflect that in this composite use of harmony the flute is worse than all the stringed instruments put together; even the panharmonic music is only an imitation of the flute? - Clearly not (Pl. Rep. 3.399c5-d9, translation Jowett).

${ }^{24}$ Slightly different from Jones' translation.

25 Barker's summary in Barker (2007) 280-81. He quotes a very useful note that Fr Duysinx wrote for Joly's Budé edition of Regimen (Joly (1967) 111-14) and which is summarized in the $C M G$ edition 239-40. $C f$. (more cautiously) Huffman (1993) 152: 'In this passage it could well be that it [lege he?] is drawing on Philolaos'.

26 Barker (2007) 55.

${ }^{27}$ Barker (2007) 56-59, also 26: 'Archytas does refer to the reed-blown pipes called auloi and to Panpipes' and not to string instruments, in his fr. 1; cf. Huffman (2005) 103-07.

\footnotetext{
28 - - The teachers of harmony compare the sounds and consonances which are heard only, and their labour, like that of the astronomers, is in vain. - Yes, by heaven! he said; and 'tis as good as a play to hear them talking about their condensed notes, as they call them; they put their ears close alongside of the strings like persons catching a sound from their neighbour's wall - one set of them declaring that they distinguish an intermediate note and have found the least interval which should be the unit of measurement; the others insisting that the two sounds have passed into the same - either party setting their ears before their understanding (P1. Rep. 7.531a4-8, translation Jowett); with Barker (2007) 23.
} 
One might wonder how the Regimen's description of organa and harmonics could explain anything in the human body and about its pathemata. The author then brings in another techne, as in the example quoted above about metallurgy and gymnastics, and introduces it by the name of the craftsmen, the cooks. However, this addition is absolutely necessary in order to understand the reference to music, and it should not be printed as a separate paragraph, as Jones does, but as a continuation of the paragraph about this musical instrument. ${ }^{29}$

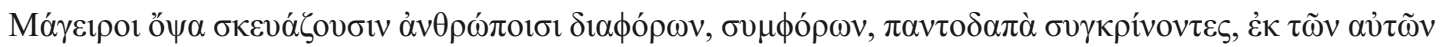

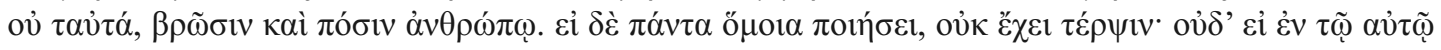

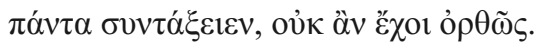

Cooks prepare for men dishes of ingredients that disagree while agreeing, mixing together things of all sorts, from things that are the same, things that are not the same, to be food and drink for a man. If the cook makes all alike, there is no pleasure, and it would not be right either if he were to compound all things in one dish (I.18, 138.18-21 J-B).

The musical aspect of cookery is well suggested: it may have been a topos at the time. Aristophanes in his Thesmophoriazousai also mixes cookery (and its savours) and music when describing

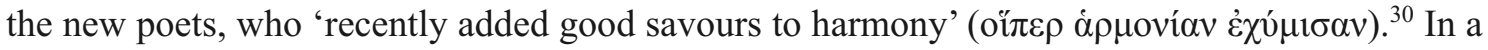
later comedy ${ }^{31}$ a cook who quotes Democritus and Epicurus is proud to explain his mastery in harmoniously mixing different humours:

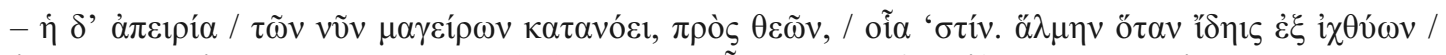

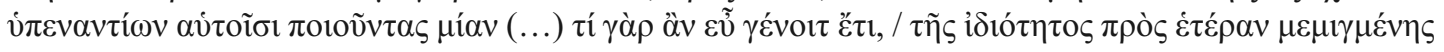

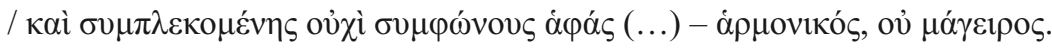

- But just look at the crass inexperience of today's cooks! Mind, when you catch them pickling in one and same brine fishes which are absolutely opposite (...). What good can there be, when a specific taste is mixed and combined with its contrary, in non-consonant touches? (...) - You are a harmonikos, not a cook! (Damoxenus 1 K-A, v. 34-36, 40-42, 49).

The cooks of Regimen are not far from this 'boastful chef'. Then the Hippocratic doctor becomes still more precise, as he comes back to music while keeping cookery in mind, through the mention of the $\gamma \lambda \tilde{\omega} \sigma \sigma \alpha$. Here again I edit a text differently from Joly.

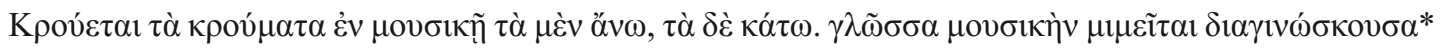

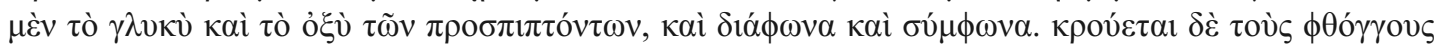

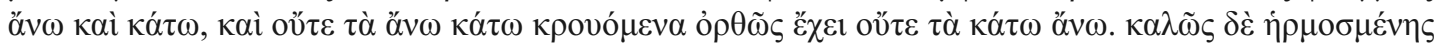

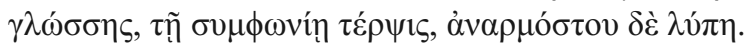

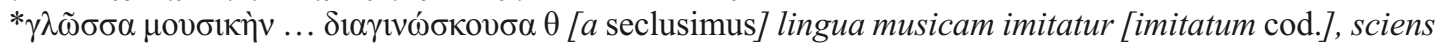

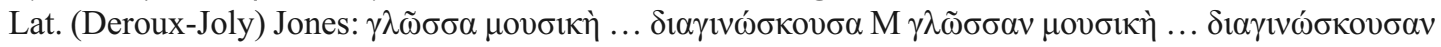
Koller, Joly-Byl.

The notes struck while playing music are some high, some low. The glossa copies music in distinguishing, of the things that touch it, the sweet and the acid, the discordant from the concordant. The glossa strikes high- or low-pitched sounds, and it is well neither when the high notes are struck low nor when the low are struck high. When the glossa is in perfect accordance with harmony, pleasure comes from the accordance, but when it is not in accordance, pain (I.18, 138.18-21 J-B, Jones' translation with alterations).

${ }^{29}$ This point is aptly made by Joly (1960) 57 . I add arguments in favour of his interpretation.
${ }^{30}$ V. 162, cf. Taillardat (1965) 441.

31 See Roselli (2000) 155-69; Wilkins (2000) 403-06. 
Joly explains: 'Music is first compared to cookery (...) Then, a connexion is made with the

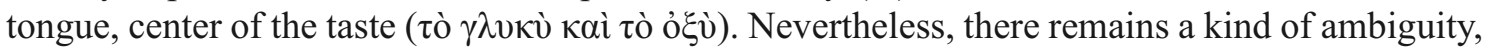
because afterwards the tongue is again quoted, but this time, it seems, about the voice, i.e. music'. ${ }^{32}$ But at the beginning of the chapter, the transmitted text sets out to consider a musical instrument that could explain the physiological affections of men. We saw that the music alluded to in the first part of the chapter is this new music which Plato vehemently condemns, especially criticizing the newer stringed instruments and auloi. When introducing the tongue, is the author really thinking of singing? Even if 'voices' are alluded to, voices, in Greek, may be voices of instruments. ${ }^{33}$ And it is the case that glossa does not only mean the tongue of a man, but also the reed of the auloi. I suggest that the doctor here compares two organa, one technical, the reed, and one physiological, the tongue (which could of course also be used in music as a technical means of producing the voice). The technical importance of the reed for producing sound in the auloi is, for example, explained in the pseudo-Aristotelian treatise De audibilibus. ${ }^{34}$

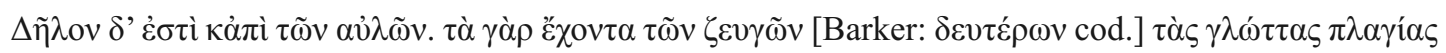

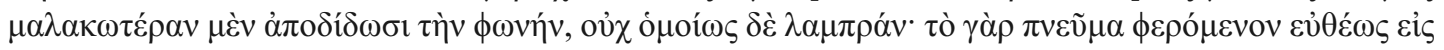

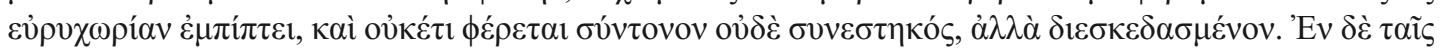

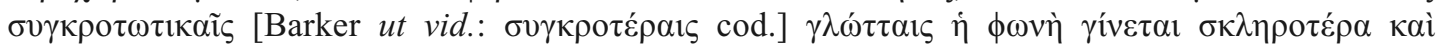

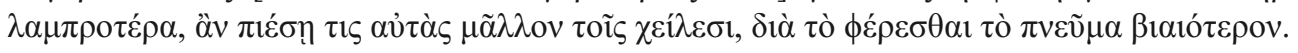

It is plain too in the case of auloi. For those mouthpieces that have their tongues angled obliquely give out a softer sound, but that is not equally bright; for as the breath travels, it falls directly into a wide space, and no longer travels under tension or compression, but is scattered. But in tongues that are closely united, the sound is harder and brighter, if one presses on them more firmly with the lips, because the breath travels more violently (801b33-42, translation Barker).

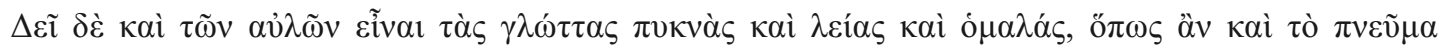

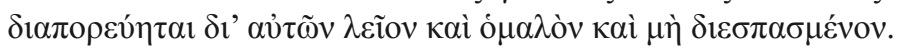

The reed-tongues of auloi should be dense and smooth and even, so that the breath may pass through them in a smooth and even state, without being dispersed (802b20, translation Barker).

Long before this text, fragment 1 of Archytas of Tarentum had already compared voice, aulos and reed, but in a different way (explaining the sound by the strength of the breath and the length of the channel) and with a different vocabulary (the reed being named kalamos).

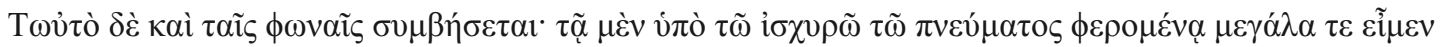

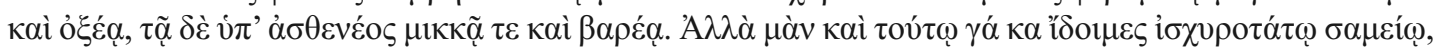

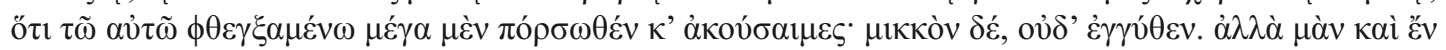

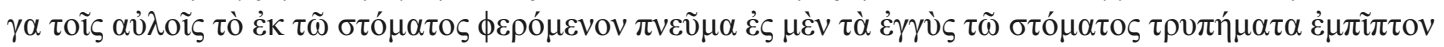

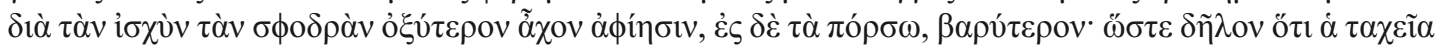

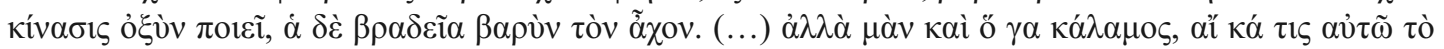

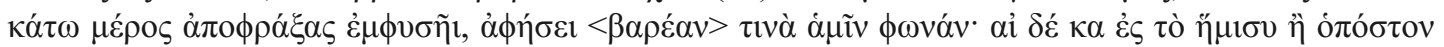

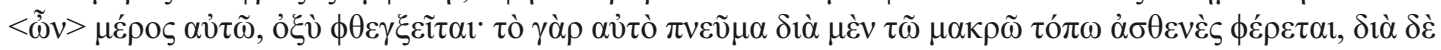

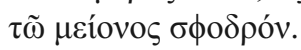

32 Joly and Byl (2003) 247; cf. chapter 23 (p. 140.21 Joly-Byl).

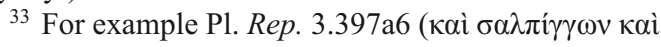

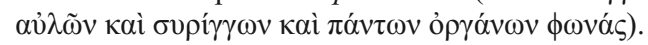

34 See Barker (1989) 99-109, esp. 103 n.17; Bélis (1984) 180, publishing Delphic auloi: 'The texts explain how unstable was the aulos, and how important for the pitches were the player's breathing, his fingering, the reed's and pipes' position'. 
The same thing will also happen with vocal sounds. The one carried by a strong breath will turn out to be loud and high, the one by a weak one, soft and low. But indeed we can see this fact from this strongest sign, that we can hear the same man speaking loudly from far off but speaking softly not even from near at hand. But indeed also in flutes, the breath moving from the mouth and falling into the openings near the mouth produces a higher sound because of the great force, but that falling into the holes further away, produces a lower sound (...). But also indeed, a reed, if someone, having blocked the lower part of it, blows in it, he will, you know, produce a low sound. But if he blows into the half or whatever part of it, it will sound high. For the same breath is carried weakly through a long distance and strongly through a shorter distance (Archytas fr. 1, text and translation Huffman).

In this way we could perhaps answer the difficulty raised by Joly: 'How would it be possible that the tongue imitates music? The tongue is part of human nature, in the same way as breath and food (...) It must be music that imitates the tongue, according to the argument'. ${ }^{35}$ In my opinion it is not the tongue but the reed, when one plays the pipe, that copies music, for music, including harmony, constitutes that part of nature which is also copied in different ways by cooks, the human body and pipes.

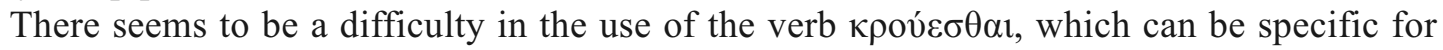
stringed instruments (hence Jones' 'struck' and Joly's 'les notes qu' on frappe'), but, as a matter of fact, this stem can also be used in a more general sense and even for playing the auloi: 'One gives the name kroumata to the aulemata, an appellation taken from the lyre', Plutarch says. ${ }^{36}$ And there are such uses in Athenian classical comedy. ${ }^{37}$ The sounds of both the voice and auloi are described by Pythagoreans as the result of a striking force and a thing struck (see n.40).

The meaning 'reed' of the word glotta was well known by Greek speakers. Aischines can make the Athenians laugh at Demosthenes by saying: 'If one snatches his glotta off, as those of auloi, he will not have anything left!' ${ }^{38}$ This joke, which remained famous throughout antiquity, was also made by Demades, it seems, about all Athenians: 'Demades compared the Athenians to auloi: if one snatches their glotta off, there is nothing left. ${ }^{39}$

The glotta (or glossa) is then an organon with its two meanings: a part of a musical instrument, the aulos, and most important in playing it, as well as a human part, a bodily organ most important in speaking, eating and singing. The mouth is of course linked to the arteria, 'windpipe' in English, and this is a significant name: Porphyry, commenting on the chapter of Ptolemy's Harmonics in which Archytas' fr. 1 is preserved, explicitly 'says [about vocal sounds] that the windpipe serves

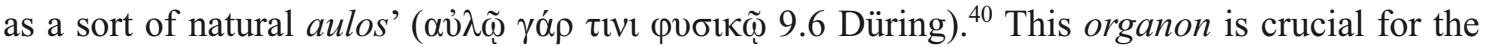
author's theory, as it is a means to create harmony: in music, in cookery and in the body. The medical associations of this comparison are not developed there, but could easily be guessed: health is also a matter of harmony, between humours, of course, as for Eryximachus in Plato's Symposium. ${ }^{41}$ This is quite coherent with the Pythagorean touch that Joly emphasizes in Regimen (above, n.4). Human nature and physiology (the taste processes of the tongue) can be understood by observing the technai of music (the use of the reed and also human singing) and cookery (the appreciation of sweetness and bitterness).

35 Joly (1960) 57: hence his correction $\gamma \lambda \tilde{\omega} \sigma \sigma \alpha v$, which he further justifies by the reading $\gamma \lambda \tilde{\omega} \sigma \sigma \alpha \mu$ ovбıкทे

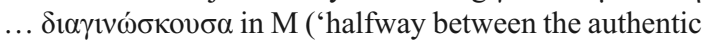
text and the corrupted one in the rest of the tradition').

${ }^{36}$ Mor. 638C1.

37 See Theopomp. Com. 51 K-A: 'Why, she plays

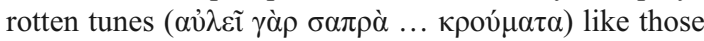
played in old Charixena's time' (translation Edmunds); cf. Eup. $121 \mathrm{~K}-\mathrm{A}$; Plb. 20.22.5.

${ }^{38}$ Aischines Against Ctesiphon 229.
39 Stobaeus Flor. IV.69.

${ }^{40}$ Huffman (2005) 146-47, who adds: 'I suggest that Archytas also drew a parallel between the aulos (or the reed) and the voice and described the movement of the voice as intervallic, insofar as it behaves in the same way as the movement of the sound of the aulos, where the pitch depends on distances between the striking force (breath) and the thing struck, the hole.'

41 186d-87d; $c f$. Demont (2004). 
There were to be further refinements of such a comparison, for example in Galen's De usu partium. There, however, the human reed is not the tongue, but the so-called glottis (the arteria being the aulos in which the air circulates), and he specifies the way in which the comparison should be made: techne imitates nature, nature does not imitate techne. ${ }^{42}$ Of course Regimen is not engaged in such late philosophical controversies. For the author it is evident that nature is prior to techne and that techne may help to understand both nature and diseases, thanks to his analysis. But it is a similar context of observations about nature and techne that paved the way for the development of the meaning '(bodily) organ' of the word organon at the beginning of the fourth century; I suggest that the doctor of Regimen exploited the polysemy of glotta in this context.

\section{Bibliography}

Barker, A. (1989) Greek Musical Writings II (Cambridge)

- (2007) The Science of Harmonics in Classical Greece (Cambridge)

Bélis, A (1984) 'III. Fragments d'auloi', BCH Supplément 9, 176-81

Bollack, J. (1965) Empédocle. 1. Introduction à l'ancienne physique (Paris)

Boudon-Millot, V. (forthcoming) 'Pourquoi les Grecs ont-ils disséqué et pourquoi ont-ils cessé de le faire?', in V. Boudon-Millot and R. Alessi (eds), Les oppositions religieuses à la dissection médicale. Le regard du médecin arabe Ibn Abī Ușaybi 'a sur ses prédécesseurs grecs, alexandrins et arabes (28-29 novembre 2013, Université de Paris-Sorbonne)

Byl, S. (1971) 'Note sur la polysémie d'ópyavov et les origines du finalisme', $A C$ 40, 121-33

Chantraine, P. (1979) La Formation des noms en grec ancien (2nd edition) (Paris)

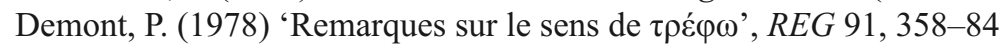

- (2004) 'Les humeurs: une question de goût', Cahiers de la Villa Kérylos 15, 53-69

Deroux, C. and Joly, R. (1978) 'La version latine du livre I du traité pseudo-hippocratique du Régime (editio princeps)', in G. Cambier, C. Deroux and J. Préaux (eds), Lettres latines du Moyen-Age et de la Renaissance (Latomus 158) (Brussels) 129-51

Diels, H. and Kranz, W. (1952) Die Fragmente der Vorsokratiker (6th edition) (Zürich and Hildesheim)

Fredrich, C. (1899) Hippokratische Untersuchungen (Berlin)

Grimm-Stadelmann, I. (2008) Theophilos: Der Aufbau des Menschen (Munich)

Helmreich, G. (1907-1909) Galeni de usu partium libri XVII (Leipzig)

Huffman, C.A. (1993) Philolaos of Croton: Pythagorean and Presocratic (Cambridge)

- (2005) Archytas of Tarentum: Pythagorean, Philosopher and Mathematician King (Cambridge)

Joly, R. (1960) Recherches sur le traité pseudo-hippocratique du Régime (Paris)

- (1967) Hippocrate, du Régime, Texte établi et traduit par Robert Joly (Paris)

— (1975) 'Les versions latines du Régime pseudo-hippocratique', Scriptorium 29, 3-22

Joly, R. and Byl, S. (2003) Hippocratis De diaeta (CMG I.2.4, 2nd edition) (Berlin)

Jones, W.H.S. (1931) Hippocrates, with an English Translation IV (Loeb Classical Library 150) (London) Jouanna, J. (1999) Hippocrates (Baltimore); translated from (1992) Hippocrate (Paris)

- (2002) Hippocratis De natura hominis (CMG I.1.3, 2nd edition) (Berlin)

- (2003) Hippocrate (II.3): La maladie sacrée (Paris)

- (2012) 'The theory of sensation, thought and the soul in the Hippocratic treatise Regimen: its connection with Empedocles and Plato's Timaeus', in J. Jouanna, Greek Medicine from Hippocrates to Galen: Selected Papers (Leiden and Boston) 195-228

\footnotetext{
${ }^{42}$ For example Galen On the Usefulness of the Parts of the Body 7 (III 353, 561 Helmreich). Glotta and glottis seem to have been equally used for the reed of pipes. $C f$. Oribasius Medical Compilations 62.27.5: 'It is remarkable that nature has achieved exactly the same kind of organ as the glottis in pipes'. For Christian authors, it became an example in order to celebrate God's Providence. $C f$. Gregorius $O n$ the Inscriptions of the Psalms (5.33) on 'the organic structure of our body', 'technically
}

adapted by nature in order to realise music'. Meletius in his Nature of Man is especially precise in his description of 'the human organ' as a harmonious mixture of aulos and lyre: $c f$. Lachenaud (2013) 57-58. Theophilus Protospatharius explains that 'this part is called glottis, similar to the glotta and the glottis of the pipes: as a matter of fact, one gives those two names to them' $(\mathrm{On}$ the Fabric of the Human Body 3.15; p. 159 1. 24-26 Grimm-Stadelmann). 
Lachenaud, G. (2013) Les Routes de la voix (Paris)

Littré, E. (1839-1861) Euvres complètes d'Hippocrate (Paris)

Lloyd, G.E.R. (1966) Polarity and Analogy: Two Types of Argumentation in Early Greek Thought (Bristol)

- (1979) Magic, Reason and Experience: Studies in the Origin and Development of Greek Science (Cambridge)

Manetti, D. and Roselli, A. (1982) Ippocrate, Epidemie: Libro Sesto (Firenze)

Olerud, A. (1951) L'idée de microcosme et de macrocosme dans le Timée de Platon (Uppsala)

Roselli, A. (2000) 'Cuisiniers-médecins dans la mésè', Cahiers de la villa Kérylos 10, 155-69

Taillardat, J. (1965) Les images d'Aristophane (Paris)

Wilkins, J. (2000) The Boastful Chief. The Discourse on Food in Ancient Greek Comedy (Oxford) 